\title{
Design and Fabrication of an Automated Solar Boat
}

\author{
Khizir Mahmud ${ }^{1,2}$, Sayidul Morsalin ${ }^{3,4}$ and Md. Imran Khan ${ }^{4}$ \\ ${ }^{1}$ Dept. of Electrical Engineering and Automation School \\ ${ }^{2}$ Northwestern Polytechnical University, P.R. China \\ ${ }^{3}$ Dept. of Electrical \& Electronic Engineering, ${ }^{4}$ Dept. of Mechanical Engineering \\ Chittagong University of Engineering and Technology, Bangladesh \\ khizirbd@gmail.com ${ }^{1}$,morsalinbd@yahoo.com ${ }^{2}$,ikhan_an_ctg@yahoo.com ${ }^{3}$
}

\begin{abstract}
Environment awareness has been developed worldwide so progressively and turns into the crying needs over the last few decades. Researchers in all disciplines have a particular obligation of development which is environmentally friendly and lead towards sustainable future development. Solar energy is a prodigious renewable energy source which has enormous energy existing as heat and light and can convert it into electricity. Besides the domestic uses, solar power can be utilized as the alternative of the oil in boat's fuel and capable of minimizing the water pollution and fuel cost as well. The purpose of this research is to design and fabricate a boat based on solar power. The boat will be conducted by the energy processed from solar by minimizing environmental pollution and fuel cost. Besides, for any cloudy or emergency condition, a backup power system integrated with the photovoltaic cell will drive the boat to make the system more secured. Both mechanical and electrical part of the boat has been designed which is found more reliable, efficient and economic.
\end{abstract}

Keywords: Boat material; photovoltaic system; renewable energy; solar boat; solar energy

\section{Introduction}

With the increasing population of the world, researchers should think about alternate sources of energy because primary sources of fuel are limited in stock. So the scientists are looking for sustainable energy sources like sun, wind, water and tidal flow. Of them solar energy is the prime source of renewable energy as it can get easily from nature. The country which has enormous solar energy potentiality can think to use it in diversified sectors. Specially, the developing and least developed country can think solar energy as a cardinal source of energy to meet energy scarcity. Alike the household solar cell and solar car, solar energy also can be a smart choice to drive the boat. Some lowland countries like Bangladesh, Indonesia and Maldives can use this kind of solar boat for its inland navigations [1]. The fabrication and installation of this solar boat is very simple and reliable. Considering the economy, fuel consumption, capacity, complexity and reliability solar energy driven boat is an innovative invention. This paper tries to find a noble approach to design and fabricate a solar powered boat that can satisfy the requirements of short transportation. The boat has a navigation capacity of $25 \mathrm{~km} /$ Day with maximum total weight of the unit of $200 \mathrm{~kg}$. The proposed solar boat has two batteries which can provide power in short cloudy periods as if it can be a reliable source of transportation. 


\section{Boat Sheet Specification}

\subsection{Main dimensions}

Different parts and overall dimension have been depicted in the following Table 1. According to the dimension, a general view to visualize the solar boat has been illustrated in the Figure 1.

Table 1. Different parts sizes of the solar boat.

\begin{tabular}{|l|l|c|}
\hline Variable & Description & Dimension (m) \\
\hline Loa & Length over all & 4.50 \\
\hline Lhull & Length hull & 4.00 \\
\hline Lwl & Length water line & 3.50 \\
\hline Boa & Breadth overall & 1.92 \\
\hline Bhull & Breadth hull & 1.50 \\
\hline Bwl & Breadth waterline & 1.30 \\
\hline D & Depth & 0.45 \\
\hline T & Drought at design & 0.23 \\
\hline H & Height & 1.65 \\
\hline
\end{tabular}

\subsection{Hydrostatic/Hydrodynamic}

Table 2. Hydrostatics and hydrodynamics data of the boat

\begin{tabular}{|l|l|l|}
\hline Lsw & Light ship weight & $200[\mathrm{~kg}]$ \\
\hline $\mathrm{Dw}$ & Deadweight & $160[\mathrm{~kg}]$ \\
\hline Vdesign & Volume at design draught & $0.360[\mathrm{~m}]$ \\
\hline $\mathrm{P}$ & Density of freshwater & $1000[\mathrm{~kg} / \mathrm{m} 2]$ \\
\hline$\Delta$ design & Displacement at design draught & $360[\mathrm{~kg}]$ \\
\hline $\mathrm{Cb}$ & Block coefficient & 0.345 \\
\hline $\mathrm{Fn}$ & Froude number & 0.358 \\
\hline $\mathrm{Gm}$ & Gm for heel $\varphi=0 \mathrm{o}$ & $0.12[\mathrm{~m}]$ \\
\hline
\end{tabular}

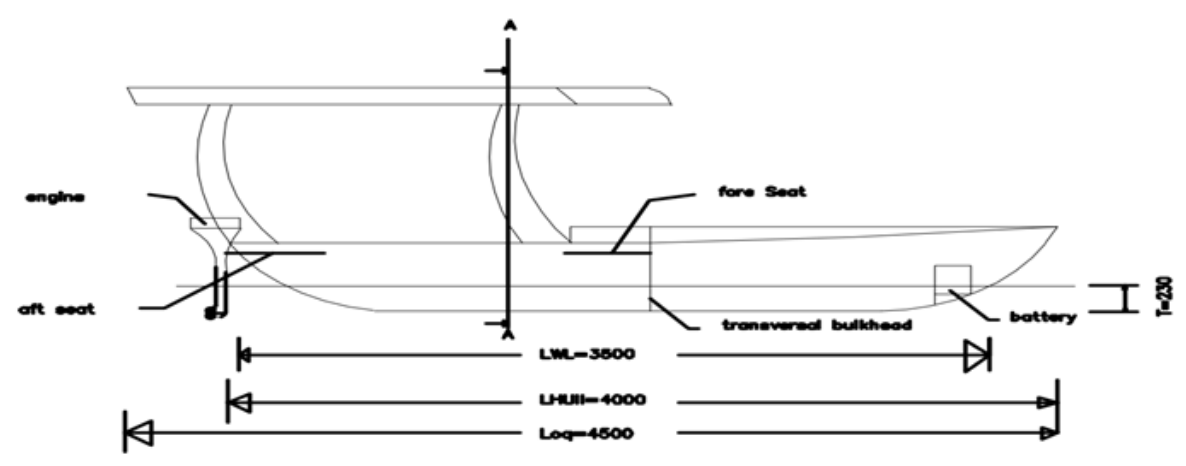

Figure 1. General view of solar boat dimension in centimeter 


\subsection{Propulsion}

Table 3. Propulsion data of the solar boat

\begin{tabular}{|c|c|c|}
\hline Notation & Description & Appearance \\
\hline $\mathrm{V}_{\max }$ & Maximum speed & $4[\mathrm{kn}]$ \\
\hline $\mathrm{P}_{\max }$ & Max. Engine power output & $2.7[\mathrm{kw}]$ \\
\hline $\mathrm{A}$ & Area solar panels & $7\left[\mathrm{~m}^{2}\right]$ \\
\hline $\mathrm{U} / \mathrm{C}$ & Voltage and capacity of the 2 batteries & $24[\mathrm{~V}] / 84[\mathrm{Ah}]$ \\
\hline
\end{tabular}

\section{Boat Material}

In order to maintain the light weight for the light ship weight (LSW) it is necessary to use light composite materials. Though the light composite material is quit expensive, but it reduces the boat weight and increase passenger carrying capacity.

Table 4. Propulsion data of the solar boat

\begin{tabular}{|l|l|l|l|c|c|}
\hline Resin & $\begin{array}{l}\text { Reinfor- } \\
\text { cement }\end{array}$ & $\begin{array}{l}\text { Density } \\
{[\mathrm{kg} / \mathrm{m} 3]}\end{array}$ & $\begin{array}{l}\text { Tensile Strength } \\
{[\mathrm{Mpa}]}\end{array}$ & $\begin{array}{l}\text { Tensile Modulus } \\
{[\mathrm{Gpa}]}\end{array}$ & $\begin{array}{l}\text { Comp. } \\
\text { Strength }\end{array}$ \\
\hline Epoxy & Aramid WR & 1330 & 517 & 31 & 172 \\
\hline Polyester & E-Glass uni & 1800 & $410-1180$ & 1241 & $210-480$ \\
\hline
\end{tabular}

Hull, bulkheads, pillars, deck, seats and roof are out of the very light Aramid WR. This has relative good material characteristics compared to the weight. The keel which has to contain the main forces and moments is out of the very strong E-Glass uni material [2].

\subsection{Different element weight}

For the determination of the weights was the hull shape approximated with geometrical surfaces like ellipses and parabolas and also with geometrical bodies like ellipsoids and parabola. For the preliminary design the precision of this method should be enough. For the following design steps however more accurate calculation methods are necessary like, e.g., SIMPSON [2].

Table 5. Weight of the different parts of the boat

\begin{tabular}{|l|l|l|l|l|l|c|}
\hline Element & $\begin{array}{l}\text { Surface } \\
{\left[\mathrm{m}^{2}\right]}\end{array}$ & $\begin{array}{l}\text { Thicknes } \\
\mathrm{s}[\mathrm{m}]\end{array}$ & $\begin{array}{l}\text { Volume } \\
{[\mathrm{m} 3]}\end{array}$ & $\begin{array}{l}\text { Density } \\
{\left[\mathrm{kg} / \mathrm{m}^{3}\right]}\end{array}$ & Material & Mass $[\mathrm{kg}]$ \\
\hline Hull aft & 6.86 & 0.005 & 0.0343 & 1330 & Aramid wr & 5.62 \\
\hline Hull fore & & 0.005 & 0.0030 & 1330 & Aramid wr & 4.07 \\
\hline Flat keel & 0.21 & 0.02 & 0.0042 & 1800 & E-glass uni & 7.54 \\
\hline Bulkhead trans. & 0.49 & 0.005 & 0.0024 & 1330 & Aramid wr & 3.28 \\
\hline Bulkhead long. & 0.83 & 0.005 & 0.0041 & 1330 & Aramid wr & 5.52 \\
\hline Deck & 2.76 & 0.004 & 0.0082 & 1330 & Aramid Wr & 4.68 \\
\hline Roof & 4.27 & 0.003 & 0.0128 & 1330 & Aramid wr & 7.04 \\
\hline Pillar & & 0.003 & 0.0007 & 1330 & Aramid wr & 1.01 \\
\hline Seat & 0.53 & 0.005 & 0.0007 & 1330 & Aramid wr & 1.01 \\
\hline
\end{tabular}


Table 6. Total weight calculation of the solar boat

\begin{tabular}{|l|c|}
\hline Element & Mi $[\mathrm{kg}]$ \\
\hline Hull & 49.69 \\
\hline Flat keel & 7.54 \\
\hline Deck & 14.68 \\
\hline Bulkhead transversal & 3.28 \\
\hline Bulkhead longitudinal & 5.52 \\
\hline Roof & 17.04 \\
\hline Solar panel deck & 16,56 \\
\hline Solar panel roof & 25.62 \\
\hline 2 fore pillars & 2.01 \\
\hline 2 aft pillars & 2.01 \\
\hline Engine & 22.00 \\
\hline 2 batteries & 30.00 \\
\hline Fore seat & 1.01 \\
\hline Aft seat & 1.01 \\
\hline & $\Sigma=198$ \\
\hline
\end{tabular}

The difference of $2 \mathrm{~kg}$ between the denoted $200 \mathrm{~kg}$ LSW in the data sheet and the $198 \mathrm{~kg}$ LSW in this table is used as a reserve. This paper contains a preliminary design. For this reason the weights were calculated with simple approximations. That means it will probably be variations in the weight during the following design stages. The reserve of $2 \mathrm{~kg}$ acts as a security factor to make sure that the total weight of the boat is less than the required $200 \mathrm{~kg}$.

\section{Boat Propulsion}

To approximate the needful power for the propulsion system, similar boats were compared to each other. The effort to use the Admiralty coefficient was not effective:

$$
\operatorname{Cadm}=\frac{\frac{2}{\sqrt[3]{V^{3}}}}{p b}
$$

Table 7. Propulsion data of different types of boat

\begin{tabular}{|l|c|c|c|c|l|}
\hline \multicolumn{1}{|c|}{ Boat } & $\mathrm{L}[\mathrm{m}]$ & $\Delta[\mathrm{kg}]$ & $\mathrm{V}[\mathrm{kw}]$ & $\mathrm{Pb}[\mathrm{kw}]$ & $\mathrm{Cadm}$ \\
\hline Woolwich 20 & 5.9 & 1000 & 5.8 & 2.4 & 8130 \\
\hline Electric Boat & 4 & 280 & 4.9 & 0.3 & 6784 \\
\hline Frauscher 560 Valencia & 5.6 & 650 & - & 4.3 & - \\
\hline Frauscher 1500 W & 5.4 & 350 & - & 1.5 & - \\
\hline Terhi (FI) Sea Fun C & 4.06 & 185 & - & 2 & - \\
\hline Frauscher 600 Riviera & 6 & 1400 & 5 & 4 & 3911 \\
\hline
\end{tabular}

Mean values: $=5.16 \mathrm{~m} ;=644 \mathrm{~kg} ;=5.2 \mathrm{kn} ;=2.4 \mathrm{kw}$

The Admiralty coefficient which is a crude but useful method of estimating power doesn't give any helpful values in this case. The main reason for that are probably the strong distinctions in the used values. As this method is confined to cases where the change in speed ( $\mathrm{V}$ in $\mathrm{kn}$ ) and displacement ( $\Delta$ in $\mathrm{kg}$ ) is relatively small. Besides the big distribution from the admiralty coefficients the table shows that the Boat is with a length $\mathrm{L}$ of $4.50 \mathrm{~m}$, a 
displacement $\Delta$ of $360 \mathrm{~kg}$ and an engine power $\mathrm{Pb}$ of $2.7 \mathrm{kw}$ for a speed $\mathrm{V}$ of 4 knots well equipped.

\section{Solar Energy}

Solar energy can be calculated according to the geographical position, solar panel area and solar panel efficiency [3]. For the practical implementation, solar energy data has been calculated according to the solar intensity of Bangladesh. The quantity of average solar energy in all seasons in Bangladesh is $1 \mathrm{kw}$ per $1 \mathrm{~m}^{2}$ terrestrial surfaces. Mono crystalline solar cells are able to convert $20 \%$ of the incoming solar energy into electrical energy:

$$
1 \frac{K W}{m^{2}} \times 0.20 \times 7.03 m^{2}=1.41 \mathrm{KW}
$$

The solar panels on the boat can provide $1.41 \mathrm{kw}$, as illustrate in the above equation.

Table 8. Solar energy data

\begin{tabular}{|l|l|}
\hline Solar constant (terrestrial) & $1 \mathrm{kw} / \mathrm{m}^{3}$ \\
\hline Effectiveness $\eta$ of the solar panels & $20 \%$ \\
\hline Surface of the solar panels & $7.03 \mathrm{~m}^{3}$ \\
\hline Area weight solar panel & $6 \mathrm{~kg} / \mathrm{m}^{3}$ \\
\hline
\end{tabular}

\section{Batteries}

The boat contains the batteries of the following type as show in the Table 9.

Table 9. Batteries specification

\begin{tabular}{|l|c|c|c|}
\hline Manufacturer & $\begin{array}{l}\text { Voltage/Capacity } \\
{[\text { V/Ah] }}\end{array}$ & $\begin{array}{l}\text { Dimensions(length x breath x height) } \\
{[\mathrm{mm}]}\end{array}$ & $\begin{array}{l}\text { Weight } \\
{[\mathrm{kg}]}\end{array}$ \\
\hline DETA GEL & $12 / 42$ & $197 \times 166 \times 175$ & 15 \\
\hline Total & $24 / 84$ & - & 30 \\
\hline
\end{tabular}

The batteries are installed in the fore part of the boat. One stands on the portside and the other one on starboard. To ensure a good maintenance for each battery is a hatch in the deck installed [4]. With the two batteries the boat can store the solar energy. So it has propulsion even under non-perfect weather conditions.

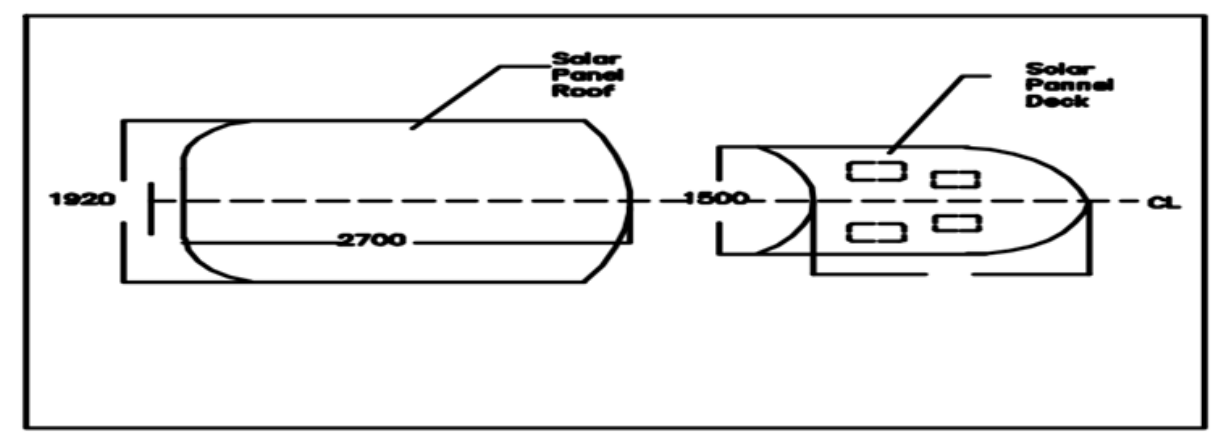

Figure 2. General view of the solar panel dimensions in centimeters 


\section{Engine}

Karvin 2700 engine has been chosen for the solar boat. The main advantage of this engine is that it can operate in direct current and has flexible options to speed control.

Table 10. Specification of KARVIN 2700 engine [5]

\begin{tabular}{|l|l|}
\hline Amp hour rating min & 80 Ah battery \\
\hline Battery voltage & $24 \mathrm{~V} / 36 \mathrm{~V} / 48 \mathrm{~V}$ \\
\hline Rpm max. & $900 / 1200 / 1500$ \\
\hline Power max. Kw/Hp & $2.7 / 3.6$ \\
\hline Torque & $27.5 \mathrm{~nm}$ \\
\hline Shaft length & long shaft $1(510 \mathrm{~mm}) /$ short shafts $(380 \mathrm{~mm})$ \\
\hline Continuous regulation & Yes \\
\hline Forward and reverse & Yes \\
\hline Engine weight & $22 \mathrm{~kg}$ \\
\hline Electronics & electronic control + electronic safety key \\
\hline
\end{tabular}

\section{Boat Stability}

For the determination of the centers of gravity of the sections valid the same as for the weight, no numerical methods were used during the preliminary design. That results in the fact that all the given data are approximations and may change in the following design steps.

Table 11. Stability data analysis

\begin{tabular}{|l|l|l|l|l|l|}
\hline Element & $\begin{array}{l}\text { Mi } \\
{[\mathrm{kg}]}\end{array}$ & $\begin{array}{l}\text { Xcgi } \\
{[\mathrm{m}]}\end{array}$ & $\begin{array}{l}\text { Mi X Xcgi } \\
{[\mathrm{kg} . \mathrm{m}]}\end{array}$ & $\begin{array}{l}\text { Zcgi } \\
{[\mathrm{m}]}\end{array}$ & $\begin{array}{l}\text { Mi x Zcgi } \\
{[\mathrm{kg} . \mathrm{m}]}\end{array}$ \\
\hline Hull & 49.69 & 1.77 & 88.05 & 0.15 & 7.50 \\
\hline Flat keel & 7.59 & 2.07 & 15.59 & 0.08 & 0.57 \\
\hline Deck & 14.68 & 2.93 & 32.23 & 0.45 & 6.61 \\
\hline Bulkhead trans. & 3.28 & 2.80 & 6.57 & 0.32 & 1.05 \\
\hline Bulkhead long & 5.52 & 2.91 & 16.06 & 0.25 & 1.40 \\
\hline Roof & 17.04 & 1.00 & 17.04 & 1.65 & 28.11 \\
\hline Solar panel deck & 16.56 & 2.93 & 48.46 & 0.45 & 7.45 \\
\hline Solar panel roof & 25.62 & 1.00 & 25.62 & 1.65 & 42.27 \\
\hline 2 fore pillars & 2.01 & 1.50 & 3.02 & 0.85 & 1.71 \\
\hline 2 aft pillars & 2.01 & 0.06 & 0.12 & 0.85 & 1.71 \\
\hline Engine & 22.00 & 3.18 & 69.96 & 0.23 & 5.06 \\
\hline 2 batteries & 30.00 & 2.80 & 84.00 & 0.09 & 2.70 \\
\hline Fore seat & 1.01 & 1.83 & 1.84 & 0.40 & 0.40 \\
\hline Aft seat & 1.01 & 0.18 & 0.18 & 0.40 & 0.40 \\
\hline 2 persons & 160.00 & 1.00 & 160.00 & 1.20 & 192.00 \\
\hline \multicolumn{1}{|c|}{$\Sigma=$} & 354.29 & $\mathrm{X}_{\mathrm{cg}}=1.63$ & 582.09 & $\mathrm{Z}_{\mathrm{cg}}=0.84$ & 298.93 \\
\hline
\end{tabular}




\section{Calculation of GM (heel $\varphi=00$ )}

$$
G M=K B+B M-K G
$$

The distance between the base line $\mathrm{K}(\mathrm{Z}=0 \mathrm{~m})$ and the centre of buoyancy in $\mathrm{z}$-direction (ZCB) equals to:

$$
K B \sim \frac{2}{3} T-\frac{2}{3} \times 0.23 m-0.15 m
$$

The distance between the centre of buoyancy in z- direction (ZCB) and the Meta centre (M) equals to:

$$
B M=\frac{I_{T}}{V} \sim \frac{L \times{ }_{B}^{3}}{12 \times V}=\frac{3.5 \mathrm{~m} \times(1.0 \mathrm{~m})^{\mathrm{a}}}{12 \times 0.360 \mathrm{~m}^{\mathrm{a}}}=0.81 \mathrm{~m}
$$

So the initial stability is:

$$
G M=K B+B M-K G=(0.15+0.81-0.84) m=0.12 m
$$

The initial stability was calculated considering 2 persons with a weight of $80 \mathrm{~kg} /$ person stand in the aft part of the boat. This was defined as the worst possible loading case. With a GM of $0.12 \mathrm{~m}$ is the initial stability good.

\section{Strength}

Strength Considering the longitudinal strength the flat keel $(50 \mathrm{~mm} \times 20 \mathrm{~mm})$ is the most important component of the boat. It is designed for lakes and rivers. So it will not be subject to the strong torsion and bending moments which can be created from heavy sea motions. But an inconvenient distribution of the deadweight in the boat can also cause significant torsion and bending moments [6]. The main structure that provides strength in the hull of the boat consists of:

- The flat keel (general longitudinal strength)

- The transversal bulkhead (receives torsion moments from the hull)

- The seats (prevent the twist of the hull through the reduction of the deck opening degree)

- The longitudinal bulkhead (prevents the warping of the transversal bulkhead and connects the keel with the deck).

- And the deck (prevents the twist of the hull and receives also the bending moments)

Besides a possible inconvenient distribution of the Deadweight the overland transport on a trailer is another critical condition regarding to the strength. In that case the whole weight of the boat rests on a few points with a relatively small area. So there can be strong area forces on the hull. Those can be increased through additional impulse forces caused by bad road conditions during the overland transport. So during the transport the forces should be introduced in the hull basically through the flat keel and from the side through the transversal bulkhead. The area of the support points should be as big as possible. Due to optical and strength reasons the cross section of the pillars is relatively big and ellipses shaped. 


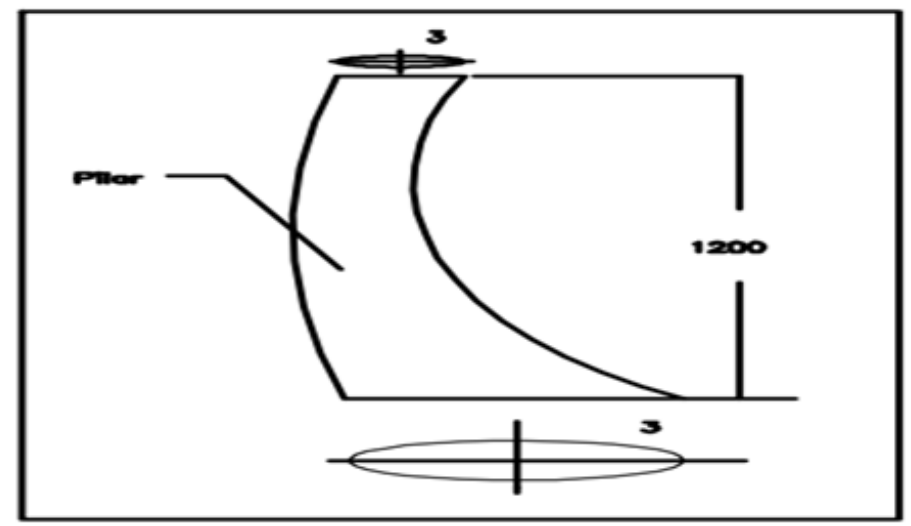

Figure 3. Cross sections of the pillar dimensions in centimeter

\section{Construction Mode}

The hull can be produced in a negative form or in a positive form. In which several layers of the material can be put on top of each other. If the hull is ready and separated from the negative form the two bulkheads which can be produced as one single part can be glued in the hull [7]. In the next step the deck (with the four holes for the hatches) must be glued on the hull. The pillars can be made around a positive form. When they are ready and separated from their form they can be installed on the hull. The connections between the pillars and the deck and the pillars and the roof are also glue connections. Like the hull the roof can be produced in a positive or negative form. When all composite parts are connected the solar panels can be bond on deck, roof and the four hatch covers. The montage of the four hatch covers is the next step. After that the electricity must be installed. That means the batteries and wires get assembled. (It may be favorable to install the batteries in the hull before the installation of the deck.) The last step is to install the engine.

\section{Electrical Systems of the Solar Boat}

\subsection{Photovoltaic system}

According to Solar Splash rules, sunlight is the only power source for charging energy storage devices used for propulsion of boat. The sunlight is converted to electric energy by photovoltaic array (PV) made from semiconductor materials. The energy delivered by PV arrays is stored in lead acid batteries or directly used by propulsion devices. The output power (OUT P) of PV arrays may not have a one sun output greater than 480 watts and open circuit voltage $(\mathrm{OC} \mathrm{V})$ cannot be greater than 52V [8]. Following the characteristic tests, it was concluded that the maximum power point (MPP) of PV array is at the knee of I - V curve and it is unique point. Moreover, since solar cells are semiconductor devices, the power delivered by the PV array depends on the irradiance, temperature, and load voltage (battery voltage) [8]. As these parameters always change during daytime, the current - voltage (I - V) characteristic of PV varies too. Due to this fact, if the PV is directly connected to load even at its MPP, it may not operate at its MPP. Therefore, the required power will not be obtained from PV array. By using bigger solar panel this limitation can be mitigate, but for bigger solar panel the expenditure will be higher. So to use maximum power point tracking circuit can be a smart solution of this problem. MPPT is a microcontroller based, high switching frequency, DC - DC converter that forces PV array to operate at its MPP under both changeable 
atmospheric conditions and load voltage situation. As battery voltage $(24 \mathrm{~V})$ is less than PV voltage (48V), a buck (step - down) converter was used. The analog signals such as voltage, current received by control circuit of MPPT were converted to digital signal by internal analog to digital converter (ADC) of microcontroller in order to be used for MPPT algorithm. Then, according to the result of MPPT algorithm, the duty cycle of buck converter was determined to operate PV array around MPP [9]. Complete electrical diagram of the solar cell is illustrated in the following Figure 4.

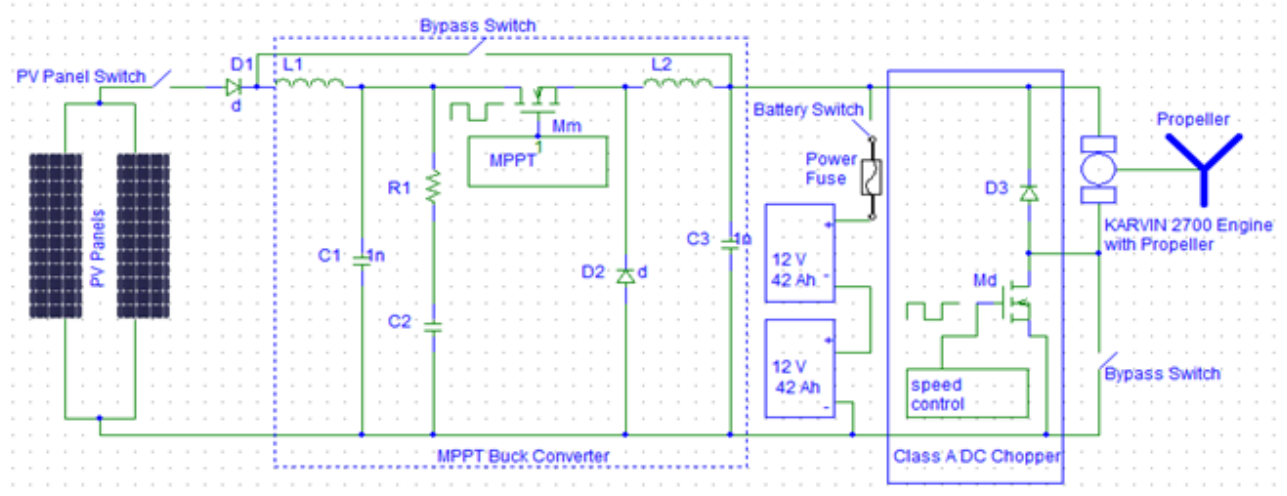

Figure 4. Electrical circuit diagram of the solar boat

\subsection{MPPT design}

The multipurpose control circuit was used as control circuit. A buck converter was designed for the solar boat because battery voltage was lower than the array voltage. Battery voltage was around $24 \mathrm{~V}$ and PV array voltage was about maximum $48 \mathrm{~V}$. The most essential part of MPPT is its control algorithm [10]. MPPT algorithm was constructed so that it increases or decreases the duty cycle in order to determine MPP as the conditionals which change the maximum power point of PV array. Since the MPP of PV array is only one point on V - P curve, the algorithms used should operate efficiently as much as it is possible to operate the PV array at this point [10]. By considering this fact, the various algorithms were tested to determine the most efficient methods. Before testing conventional MPPT methods, the PV array was operated at its MPP by manually adjusting duty cycle of buck converter to monitor MPP points during atmospheric condition changes [11].

\subsection{Motor Controller}

A first- quadrant (Class A) DC chopper illustrated in fig. 5 was designed and manufactured for controlling motor speed. In this part, a constant DC voltage has to be converted into a variable DC voltage to control the speed of motor. In this type of choppers, current and voltage values of load are both positive indicating a single-quadrant operation [12]. DC choppers have several advantages like soft start, smooth speed control and high efficiency [14]. For the control part of this chopper, the same multipurpose control circuit was used. The control circuit can also be designed by the commercially available PIC microcontroller [13]. 


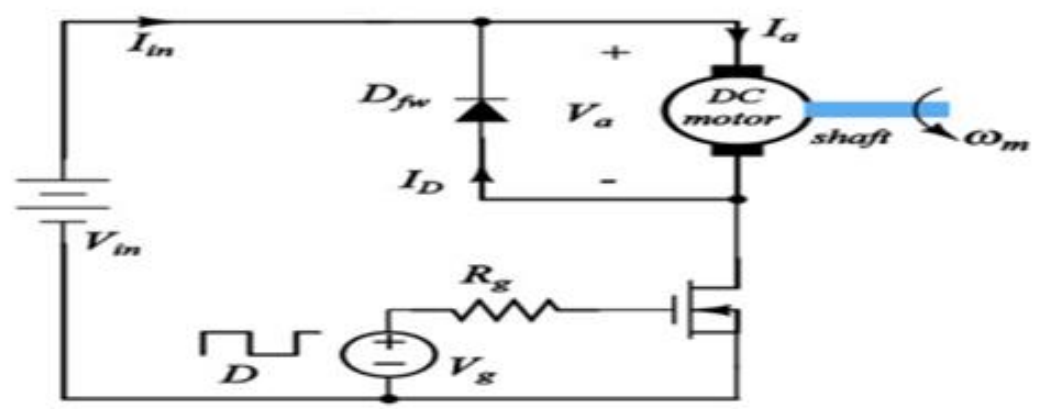

Figure 5. Class-A single quadrant DC chopper

\section{Conclusion}

Scientist always insists that this is the high time to minimize the dependency of fuel of conventional energy sources gradually and side by side to encourage the renewable energy sources. For this reason the use of solar energy in boat for inland navigation of developing countries can help a lot to reduce fossil fuel dependency and minimize cost. The boat is designed both electrically and mechanically for a particular weight carrier and particular distance. So if the number of passenger and distance changes then photovoltaic cell, emergency battery and engine specification should change according to the condition. Based on simple design, cost minimization, efficiency and reliability, this proposed boat can be a best option for pollution free green inland navigation system.

\section{References}

[1] M. Khizir, "Fuel Cell and Renewable Hydrogen Energy to Meet Household Energy Demand", International Journal of Advanced Science \& Technology, vol. 54, (2013).

[2] M. C. Ozden and E. Demir, "The Successful Design and Construction of Solar/Electric Boats Nusrat and Muavenet: An Overview", Ever Monaco 2009 Conferences on Ecological Vehicles and Renewable Energies, Monte Carlo, (2009) March 27- 29.

[3] R. Leiner, "Research solar power boat-data management and online visualization", IEEE, AFRICON, (2007), pp. $1-5$.

[4] C. A. Hill, C. S. Matthew, D. Chen, J. Gonzalez and W. Mack Grady, "Battery energy storage for enabling integration of distributed solar power generation", IEEE Transactions on Smart Grid, vol. 3, no. 2, (2012).

[5] N. De Castro, J. Carlos and A. Rössling, "Development of Solar Powered Boat for Maximum Energy Efficiency", International Conference on Renewable Energies and Power Quality (ICREPQ'12), Santiago de Compostela, Spain, (2012) March 28-30.

[6] C. Rivera-Solorio, A. J. Garcia-Cuellar and A. Flores, "Design and construction of a boat powered by solar energy with the aid of computational tools", International Journal of Engineering Education, vol. 29, no. 2, (2013), pp. 380-387,

[7] M. Bieger, B. Sisson, A. Unger, K. Ward and A. Youngstrom, "Solar boat hull design", Northeastern Univerity, US, (2012).

[8] Y. Yushaizad, S. H. Sayuti, M. A. Latif, M. Zamri and C. Wanik, "Modeling and simulation of maximum power point tracker for photovoltaic system", IEEE In Power and Energy Conference, 2004. PECon 2004. Proceedings. National, (2004), pp. 88-93.

[9] X. Sun, W. Wu, X. Li and Q. Zhao, "A research on photovoltaic energy controlling system with maximum power point tracking. In Power Conversion Conference, 2002. PCC-Osaka 2002. Proceedings of the IEEE, vol. 2, (2002), pp. 822-826.

[10] J. -M. Kwon, B. -H. Kwon and K. -H. Nam, "Three-phase photovoltaic system with three-level boosting MPPT control." IEEE Transactions on Power Electronics, vol. 23, no. 5, (2008). 
[11] K. Eftichios, K. Kalaitzakis and N. C. Voulgaris, "Development of a microcontroller-based, photovoltaic maximum power point tracking control system", Power Electronics, IEEE Transactions on, vol. 16 no. 1, (2001).

[12] K. Matti and M. Silvennoinen, “Arrangement for a motor controller. U.S. Patent No. 8004836, (2011) August 23.

[13] K. Mahmud, M. S. Alam and R. Ghosh, "Design of digital thermometer based on PIC16F77A single chip microcontroller", 3rd International Conference on Consumer Electronics, Communications and Networks (CECNet), IEEE, (2013) November 20-22, Xianning, P.R. China

[14] I. Mohd and A. Bakar, "DC Motor Controller", UTem, Malaysia, (2008).

\section{Authors}
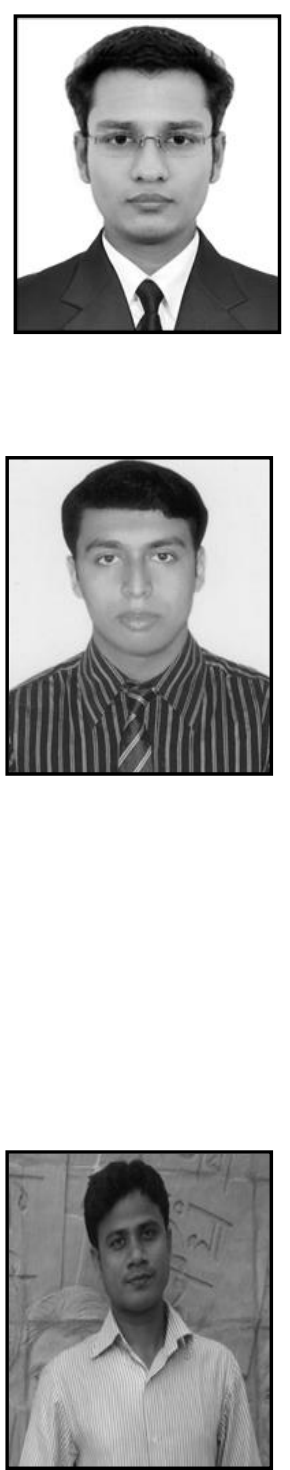

\section{Khizir Mahmud}

Khizi Mahmud received B.Sc. degree in Electrical and Electronic Engineering from Chittagong University of Engineering and Technology (CUET), Bangladesh. He received Russian and Chinese govt. scholarship for his excellent academic performance. Currently, he is completing his M. Sc. degree from Northwestern Polytechnical University, P. R. China. His research interests include renewable energy, electrical power, power conversion, power factor, power electronics and artificial intelligence.

\section{Sayidul Morsalin}

Sayidul Morsalinreceived Bachelor of Science (B.Sc.) degree in Electrical and Electronic Engineering from Chittagong University of Engineering and Technology (CUET), Bangladesh. Currently, he is working as a lecturer in the Department of Electrical and Electronic Engineering at European University of Bangladesh (EUB), Bangladesh. During his academic life he got many scholarships and awards especially notable Imdad-Sitara Khan Scholarship provided by Khan Family Foundation, U.S.A, coordinated by SpaandanB and Genius Scholarship provided by CZM with the support of A. K. Khan Foundation. He is skilled in Cadence EDA Tool, MATLAB and AutoCAD. His research interests include renewable energy, digital electronics, power system, artificial intelligence, VLSI and Power electronics.

\section{Md. Imran Khan}

Md. Imran Khan received B.Sc. degree in Mechanical Engineering from Chittagong University of Engineering and Technology (CUET), Bangladesh. Currently, he is working as an Engineer in Bangladesh Steel Rerolling Mills Ltd (BSRM), Bangladesh. His research interests include naval architecture, renewable energy and production management. 
International Journal of Advanced Science and Technology Vol.64 (2014) 